\title{
Implementasi Kegiatan Ekstrakurikuler Dalam Membentuk Karakter Peserta Didik di Mts. Al-Ma'arif Wuluhan Jember
}

\author{
Amirotun Nahdliyah ${ }^{1}$, Arina Faiqotul Himmah ${ }^{2}$ \\ e-mail : amirohnahdliyah@gmail.com ${ }^{1}$, arinaalfaiqiy10@gmail.com ${ }^{2}$ \\ Program Studi Manajemen Pendidikan Agama Islam \\ Institut Agama Islam Darussalam Blokagung Banyuwangi
}

\begin{abstract}
This study is to answer three problem formulations, namely (1) How are extracurricular activities at MTs. Al-Maarif Wuluhan Jember? (2) How is the implementation of extracurricular activities in shaping the character of students in MTs. Al-Maarif Wuluhan Jember? (3) What are the supporting and inhibiting factors for extracurricular activities in MTs. Al-Maarif Wuluhan Jember? Therefore, the type of research chosen is qualitative with a descriptive approach. Data analysis with the process of data reduction, data presentation and conclusions. From the observation process, interviews and documentation resulted in the following conclusions: (1) Extracurricular activities at MTs. Al-Maarif Wuluhan Jember is carried out only on Saturdays as many as 8 types of curricular activities are sustainable, namely the Olympics Studio, Tsalma Scout Scouts, Pagar Nusa, Volly Ball, Tsalma Futsal Club, Badminton, Sholawat Majlis, and Tahfidzul Quran. (2) The implementation of extracurricular activities in shaping the character of students is contained in scout extracurricular activities, namely camps, bonfires and ceremonies. (3) Supporting factors include the presence of competitions, the presence of alumni, active coaches, support from parents and additional time on Friday afternoons. The inhibiting factors are the lack of student commitment, no definite syllabus, lack of facilities and infrastructure, teaching staff and funds.
\end{abstract}

Keywords: extracurricular activities, student character

\begin{abstract}
Abstrak
Penelitian ini guna menjawab tiga rumusan masalah yakni (1) Bagaimana kegiatan ekstrakurikuler di MTs. Al-Maarif Wuluhan Jember? (2) Bagaimana implementasi kegiatan ekstrakurikuler dalam membentuk karakter peserta didik di MTs. Al-Maarif Wuluhan Jember? (3) Apa faktor pendukung dan penghambat proses kegiatan ekstrakurikuler di MTs. Al-Maarif Wuluhan Jember? Maka dari itu jenis penelitian yang dipilih adalah kualitatif dengan pendekatan deskriptif. Analisis data dengan proses reduksi data, penyajian data dan kesimpulan. Dari proses obervasi, wawancara dan dokumnetasi menghasilkan kesimpulan: (1) Kegiatan ekstrakurikuler di MTs. Al-Maarif Wuluhan Jember dilakukan hanya pada hari Sabtu sebanyak 8 jenis kestrakurikuler yang bersifat berkelanjutan yaitu Sanggar Olimpiade, Pramuka Tsalma Scout, Pagar Nusa, Volly Ball, Tsalma Futsal Club, Bulu tangkis, Majlis
\end{abstract}

Implementasi Kegiatan Ekstrakurikuler dalam Membentuk Karakter Peserta Didik di Mts. Al-Maarif Wuluhan Jember

Amirotun Nahdliyah, Arina Faiqotul Himmah 
Sholawat, dan Tahfidzul Quran. (2) Implementasi kegiatan ekstrakurikuler dalam membentuk karakter peserta didik terdapat dalam kegiatan ekstrakueikuler pramuka yaitu perkemahan, api unggun dan upacara. (3) Faktor pendukung meliputi adanya perlombaan, hadirnya alumni, aktifnya pembina, dukungan orang tua dan waktu tambahan pada Jumat sore. Faktor penghambatnya ialah kurangnya komiten peserta didik, tidak ada silabus yang pasti, kurangnya sarana dan prasarana, tenaga pendidik dan dana.

\section{Kata Kunci: Kegiatan Ekstrakurikuler, Karakter Peserta Didik}

\section{A. Pendahuluan}

\section{Latar Belakang Masalah}

Negara Kesatuan Republik Indonesia. Mendengar nama Indonesia menggambarkan sebuah tanah kelahiran yang subur, makmur, riang, penuh kebersamaan, dikelilingi suasana perdamaian, masyarakat saling gotong royong, mengadu tawa dan cerita-cerita nenek moyang. Suasana inilah yang nenek moyang impikan dan perjuangkan untuk mempertahankan nama bangsa Indonesia yang berideologi Pancasila. Dijelaskan juga dalam Sisdiknas bahwa "Pendidikan Nasional bertujuan membentuk manusia yang beriman juga bertakwa kepada Tuhan YME, berakhlak, berbudi mulia, berilmu, sehat, cakap, serta menjadi warga negara yang demokratis dan bertanggung jawab terhadap kesejahteraan masyarakat dan tanah air'(UU. RI. No. 20 Tahun 2003 Pasal 4 ayat 1, dalam Sukiyat, 2020:46).

Kompas.com-04/20/2020, 09:30 WIB mengabarkan "DIY darurat klitih ramai di Twitter yang sempat menggegerkan warga". Setelah ditelusuri hal itu terjadi dikarenakan munculnya beberapa kasus kenakalan remaja di Yogyakarta yang dikenal dengan nama klitih. Dalam bahasa Jawa, klitih adalah suatu aktivitas mencari angin di luar rumah atau keluyuran. Namun dalam kekerasan remaja Jogja, pemaknaan klitih kemudian berkembang sebagai aksi kekerasan atau kejahatan jalanan dengan istilah klitih atau tindak-tanduk anak di bawah umur di luar kelaziman. Korban terbaru dengan nama Fatur Nizar Rakadio (16) meniggal dunia, kamis (9/1/2020). Fatur menjadi korban klitih di Daerah Selopamioro, Imogiri, Bantul, pada Desember 2019 lalu. Klitih merupakan jenis 
kenalakan remaja yang berupa sekelompok pelajar (geng pelajar) yang melakukan tindakan kekerasan dan kriminalitas. Kekerasan pelajar ini dilatarbelakangi dengan masalah sepele, mungkin percekcokan kecil, perbedaan pendapat yang menyebabkan hilangnya nyawa. Beberapa senjata tajam yang berhasil diamankan Polresta Yogyakarta dari pelaku klitih di Jl. Kenari, Kota Yogyakarta berupa 1 pisau, 2 sabit, 2 gir rantai. Melihat berita ini peneliti menjadi prihatin dan hawatir akan pemuda generasi bangsa Indonesia ini tidak mampu memperjuangkan cita-cita bangsa, tidak mampu menghadapi tantangan bangsa dan justru malah menjadi beban para petua.

Contoh kericuhan pelajar yang kurang mendukung cita-cita bangsa ini didasari karena belum adanya karakter yang terbentuk secara menyeluruh. Karakter kejujuran, saling memaafkan, gotong royong, toleransi, menghargai sesama, menjunjung persatuan, mempertahankan perdamaian, bermusyawarah, adil dan bijaksana dalam sekelompok pelajar ini. Sikap gegabah dan emosi yang sensitive menyebabkan tawuran pelajar sering terjadi. Hal ini juga dikarenakan kurangnya kegiatan yang bermanfaat, kurang sadarnya pelajar akan kewajibannya untuk meningkatkan kualitas belajar, mengaplikasikan apa yang sudah didapat dan sesuatu yang sudah diberikan oleh guru. Seseorang yang berkarakter akan mengerti mana hal yang baik mana yang buruk, mana yang sesuai dan mana yang tidak sesuai, mana yang baik dilakukan dan mana yang perlu dihindari. Mereka akan bertindak sesuai dengan kata hati dan moral yang semestinya. Bukan bertindak sesuai dengan nafsu, ego dan keinginan sepihak saja. Jika mereka memahami dengan apa yang sudah didapat di sekolah seperti materi kewarganegaraan dan agama, mereka akan menjunjung tinggi persatuan dan saling menghargai antar sesama, karena mereka tau bahwa berargumentasi adalah hak semua orang. Jika ada perbedaan argumentasi bisa diselesaikan melalui musyawarah, itulah yang sudah diajarkan oleh nenek moyang bangsa Indonesia dalam Pancasila.

Implementasi Kegiatan Ekstrakurikuler dalam Membentuk Karakter Peserta Didik di Mts. Al-Maarif Wuluhan Jember 
Maka dari itu pendidikan mempunyai tugas yang sangat penting untuk mewujudakan cita-cita bangsa yakni bangsa Indonesia yang berkarakter Pancasila. Bidang garapan dasar yang dikembangkan oleh pendidikan salah satunya adalah peserta didik. Peserta didiklah yang menjadi objek utama keberhasilan suatu pendidikan. Peserta didiklah yang menjadi generasi bangsa. Dapat dibuktikan jika kualitas peserta didik bagus maka sekolah akan mendapat apresisasi yang bagus pula, jika kualitas peserta didik masih perlu dibina kembali maka sekolahpun juga kurang mendapat apresiasi dari masyarakat. Jalan efektif yang bisa membentuk karakter bangsa yaitu dengan memperhatikan karakter pemuda dan pelajar.

Upaya sekolah dalam mengembangkan dan membina peserta didik melalui kegiatan kurikuler dan ektrakurikuler. Kurikuler merupakan kegiatan peserta didik yang berada di dalam kelas seperti kegiatan belajar mengajar efektif yang menggeluti materi-materi yang bisa menambah kecerdasan kognitif (pengetahuan). Sedangkan ekstrakurikuler merupakan nama suatu kegiatan peserta didik yang terkesan santai, berada di luar kelas, belajar sambil bermain untuk meningkatkan kecerdasan afektif dan psikomotorik. Ekstrakurikuler diikuti oleh peserta didik sesuai dengan minat bakat masing-masing. Dalam melaksanakan kegiatan-kegiatan ini peserta didik akan menerima pengetahuan, teknik-teknik keterampilan yang didalami, belajar bersosial, saling membantu, berkompetisi secara sehat, saling mengingatkan, belajar untuk berani berada di depan, berani berbicara di depan teman-teman, dan masih banyak lagi manfaat yang dapat dinikmati oleh peserta didik. Output yang diharapkan sekolah adalah peserta didik tidak hanya menguasai bidang intelegensi saja namun juga harus mempunyai skill yang bisa menjadi bekal mencari jati diri guna menjadi seseorang yang bisa berperan aktif di masyarakat.

Peneliti memandang fokus pada ekstrakurikuler karena kegiatannya terkesan menarik, menyenangkan dan dipilih sendiri oleh peserta didik. Berbeda dengan kurikuler, kurikuler sudah masuk pada rombongan belajar dalam satu 
semester atau satu periode pembelajaran dengan kurikulum yang sudah diatur oleh sekolah atas dasar peraturan Kementrian Pendidikan, kegiatan hanya di dalam ruang kelas. Dari ektrakurikuler, apakah karakter bangsa bisa dibentuk? Pertanyaan menarik untuk meneliti lebih lanjut. Pembentukan moral bangsa bisa dimulai melalui pendidikan karakter, sedangkan pendidikan karakter dapat disalurkan melalui kegiatan ekstrakurikuler pramuka.

Gerakan Pramuka merupakan salah satu kegiatan ekstrakurikuler yang memiliki visi, misi, arah, tujuan dan strategi yang jelas. Pendidikan kepramukaan dalam Sistem Pendidikan Nasional termasuk dalam jalur pendidikan nonformal yang diperkaya dengan pendidikan karakter yang dikemas dalam nilai-nilai gerakan pramuka dalam pembentukan kepribadian yang berakhlak mulia, berjiwa patriotik, taat hukum, disiplin, menjunjung tinggi nilai-nilai luhur bangsa, dan memiliki kecakapan hidup. Dalam UU. No. 12 Tahun 2010 Tentang Gerakan Pramuka disebutkan bahwa pembangunan kepribadian ditujukan untuk mengembangkan potensi diri serta memiliki akhlak mulia, pengendalian diri, dan kecakapan hidup bagi setiap warga Negara demi tercapainya kesejahteraan masyarakat (Sukiyat, 2020:98).

MTs. Al-Maarif Wuluhan merupakan madrasah yang berada di bawah naungan Yayasan Pondok Pesantren Islam Bintang Sembilan (YASPPIBIS). Peneliti menemukan kegiatan ekstrakurikuler yang menarik di sini, mulai dari olahraga futsal, sepakbola, bulu tangkis, tenes meja, bola voli, atletik, juga kesenian berupa khitabah, qira'ah, melukis, kaligrafi, menyanyi, paduan suara, theater, puisi, seni beladiri, tari, pramuka, shalawatan, jam'iyyah tahfidzil quran, Karya Ilmiah Remaja (KIR), Palang Merah Remaja (PMR), tim olimpiade MIPA, tim olimpiade IPS. Semua disiapkan agar peserta didik memiliki wawasan dan kepribadian yang siap menghadapi era industri 4.01. Pada periode pembelajaran 2019-2020 Gugus depan satuan MTs. Al-Maarif mengikuti lomba Pramuka terampil di Kecamatan Balung. Lomba meliputi PBB, pionering, PPGD, ketangkasan dan ketangguhan, kreasi dan inovasi, bela negara, dll. MTs. Al- 
Maarif juga mengadakan Wisuda Tahfidzil Quran (WTQ) 5 juz pada 20 Januari 2020 kemarin berjumlah 43 santri. MTs. Al-Maarif juga telah meraih sederet prestasi di lomba Pramuka Penggalang se-Kab. Jember pada 23 september 2019. Begitu banyak ladang bagi peserta didik untuk berkreasi mengembangkan bakat sesuai minat masing-masing. Dan bagaimana sekolah mengelola semua kegiatan ini agar dapat dinikmati oleh seluruh peserta didik. Namun juga ada sebagian peserta didik yang menjadi golongan putih maksudnya tidak mengikuti ekstrakurikuler sama sekali.

Peneliti berharap dengan adanya ekstrakurikuler di sekolah ini dapat dijadikan jembatan pembentukan karakter bangsa karakter Pancasila. Tetap bertujuan pada pembentukan karakter melalui kegiatan-kegiatan ekstrakurikuler yang telah diatur oleh manajemen sekolah masing-masing. Maka dari itu peneliti tertarik untuk meneliti kegiatan ekrtrakurikuler tersebut dengan mengangkat judul "Implementasi Kegiatan Ekstrakurikuler Dalam Membentuk Karakter Peserta Didik Di MTs. Al-Maarif Wuluhan Jember Tahun Pembelajaran 2019/2020”. Penentuan objek penelitian ini dikarenakan sebaiknya pembentukan karakter dimulai sejak dini, lokasi penelitian terjangkau, ekstrakurikuler di MTs ini juga masih exis berjalan rutin setiap minggunya.

\section{Rumasan Masalah}

a. Bagaimana kegiatan ekstrakurikuler di MTs. Al-Maarif Wuluhan Jember?

b. Bagaimana implementasi kegiatan ekstrakurikuler dalam membentuk karakter peserta didik di MTs. Al-Maarif Wuluhan Jember?

c. Apa faktor pendukung dan penghambat proses kegiatan ekstrakurikuler di MTs. Al-Maarif Wuluhan Jember?

\section{Tujuan Penelitian}

a. Mengetahui dan mendeskripsikan kegiatan ekstrakurikuler di MTs. AlMaarif Wuluhan Jember.

Implementasi Kegiatan Ekstrakurikuler dalam Membentuk Karakter Peserta Didik di Mts. Al-Maarif Wuluhan Jember 
b. Mengetahui dan mendeskripsikan implementasi kegiatan ekstrakurikuler dalam membentuk karakter peserta didik di MTs. Al-Maarif Wuluhan Jember.

c. Mengetahui dan mendeskripsikan faktor pendukung dan penghambat proses kegiatan ekstrakurikuler di MTs. Al-Maarif Wuluhan Jember

\section{B. Tinjauan Pustaka}

\section{Pengertian Manajemen Pendidikan Islam}

Manajemen adalah "ilmu dan seni mengatur sumber daya manusia untuk mencapai tujuan secara efektif dan efisien" (Saefullah, 2014:1). Pendidikan Islam adalah "pengajaran yang dilakukan di sekolah berbasis islam" (Maunah, 2009:5). Jadi, manajemen pendidikan islam adalah seni mengatur sumber daya manusia dalam melaksanakan pengajaran berdasarakan keislaman baik di dalah kelas maupun di luar kelas untuk mencapai tujuan secara efektif dan efisien.

Kemudian Widyantari (2015:5) menyebutkan bidang garapan manajemen pendidikan ada 8 yakni "manajemen kurikulum, kesiswaan, sarana dan prasarana, tenaga pendidikan dan kependidikan, keuangan, hubungan sekolah dan masyarakat, layanan khusus, tenaga manajemen sekolah". Sementara manajemen kesiswaan atau peserta didik adalah "pengaturan peserta didik mulai dari awal menginjak pendidikan sampai lulus sekolah" (Prihatin, 2014:4). Ruang lingkup manajemen peserta didik yakni perencanaan, penerimaan, pengelompokan, memeriksa kehadiran peserta didik, pembinaan peserta didik, kenaikan, kelulusan dan kegiatan ekstrakurikuler. Maka dari itu tema penelitian ini termasuk dari bidang garapan menejemen peserta didik atau kesiswaan.

\section{Kegiatan Ekstrakurikuler}

\section{a. Pengertian Kegiatan Ekstrakurikuler}

Implementasi Kegiatan Ekstrakurikuler dalam Membentuk Karakter Peserta Didik di Mts. 
Mamad (dalam Sariyat, 2020:80) mengartikan "ekstrakurikuler sebagai kegiatan pendidikan yang dilakukan di luar jam pelajaran tatap muka ditujukan untuk membantu perkembangan peserta didik, sesuai dengan kebutuhan, bakat dan minat mereka melalui kegiatan yang secara khusus diselenggarakan oleh pendidik yang berkemampuan dan berwenang di sekolah". Sedangkan Nasihin dan Sururi (2009:212) menjelaskan ekstrakurikuler adalah "kegiatan peserta didik yang dilaksanakan di luar ketentuan yang telah ada di dalam kurikulum berdasarkan minat bakat peserta didik". Sementara itu ada yang menyebut program ekstrakurikuler yang ternyata berbeda dengan kegiatan ekstrakurikuler. Hal ini selaras dengan penjelasan bahwa program ekstrakurikuler adalah "sederetan kegiatan yang akan dilaksanakan untuk mencapai suatu tujuan tertentu sedangkan kegiatan ekstrakurikuler adalah kegiatan tambahan di luar struktur program yang pada umumnya merupakan kegiatan pilihan" (Arikunto, Tanpa Tahun).

Pendidikan saat ini bersifat desentralisasi yang mana seluruh aturan sekolah dikembalikan ke sekolah masing-masing dan untuk kurikulum pendidikan Indonesia yang terbaru mewajibkan pendidikan kepramukaan masuk pada kurikulum pendidikan dan menjadi kegiatan ekstrakurikuler wajib pada pendidikan dasar dan menengah melalui Peraturan Mentri Pendidikan dan Kebudayaan Nomor 63 Tahun 2014 tentang Pendidikan Kepramukaan. Salah satu isi dari Peraturan itu berbunyi "Pendidikan Kepramukaan dilaksanakan untuk menginternalisasikan nilai ketuhanan, kebudayaan, kepemimpinan, kebersamaan, sisoal, kecintaan alam dan kemandirian pada peserta didik" (Sukiyat, 2020:63).

Untuk mengimplementasikan nilai dasar kepramukaan (Dasa Dharma) kepada peserta didik diperlukan Metode Kepramukaan untuk 
mengetahui cara belajar interaktif profresif $^{1}$ melalui pengamalan Kode Kehormatan Pramuka berupa Dasa Dharma dan Tri Satya, belajar sambil melakukan, sistem berkelompok, kegiatan yang menantang dan mengandung pendidikan yang sesuai dengan perkembangan jasmani dan rohani peserta didik, kegiatan di alam terbuka, sistem tanda kecakapan, sistem satuan terpisah antara putra dan putri dan sistem among

Adapun fungsi dan tugas kepramukaan adalah "kegiatan menarik bagi anak atau pemuda, pengabdian bagi orang dewasa, alat bagi masyarakat dan organisasi” (Sukiyat, 2020:131). Selaras dengan Kurikulun 2013 yang menanamkan nilai-nilai yang bersumber dari pancasila juga Sebagian masuk dalam nilai-nilai kepramukaan. Adapun muatan nilai sikap dan Kecakapan Pendidikan Kepramukaan sudah tercantum dalam Syarat Kecakapan Umum (SKU) berupa: “1) keimanan kepada Tuhan YME, 2) ketakwaan kepada Tuhan YME, 3) kecintaan pada alam, 4) kecintaan kepada sesama manusia, 5) kecintaan kepada Tanah Air Indonesia, 6) kecintaan kepada Bangsa Indonesia, 7) kedisiplinan, 8) keberanian, 9) kesetiaan, 10) tolong-menolong, bertanggungjawab, 11) dapat dipercaya, 12) jernih dalam berpikir, 13) jernih dalam berkata, 14) jernih dalam berbuat, 15) hemat, 16) cermat, 17) bersahaja, 18) rajin dan 19) terampil" (Sukiyat, 2020:144).

Dalam mencapai tujuan pramuka perlu diadakan kegiatan yang berguna untuk menambah pengetahuan anggota agar moral, mental serta jiwa disiplin terbentuk. Kegiatan ekstrakurikuler Pamuka meliputi:

\section{(a) Perkemahan}

Perkemahan merupakan kegiatan yang membutuhkan mental individu dan kelompok karena kegiatannya pergi ke alam bebas disaat libur sekolah, mendirikan tenda, mengenal alam dan memanfaatkan bahan yang ada di alam untuk bertahan hidup. Kegiatan perkemahan ini diadakan bermaksud untuk mempraktikan kepada peserta didik cara bersosisalisasi dan kerjasama dalam beregu, mempraktekkan

\footnotetext{
${ }^{1}$ Interaktif prosesif menurut KBBI adalah saling aktif.

Implementasi Kegiatan Ekstrakurikuler dalam Membentuk Karakter Peserta Didik di Mts. Al-Maarif Wuluhan Jember Amirotun Nahdliyah, Arina Faiqotul Himmah
} 
pembinaan beragama, pembinaan jasmani dan rohani, sebagai media uji diri dalam menghadapi masalah. Kegiatan perkemahan tidak dilaksanakan secara cuma-cuma, kegiatan ini juga mempunyai tujuan yaitu

"untuk meningkatkan keyakikan dan ketaqwaan terhadap Tuhan atas kekuasaan dan kebesarannya menciptakan alam yang patut untuk disyukuri dan dijaga, membina mental dan kepercayaan pada diri sendiri, meningkatkan kesehatan dan daya tahan tubuh, meningkatkan daya kreasi, ketangkasan, dan keterampilan, membina kerjasama, gotong royong, dan kerukunan, memperluas pengetahuan dan menambah pengalaman, menanamkan kecintaan pada tanah air dan menumbuhkan kesadaran untuk berbakti" (Sukiyat, 2020:173).

Perkemahan dalam kepramukaan mempunyai banyak macam, salah satunya dilihat dari segi waktu terdapat 3 macam perkemahan, yaitu persari (perkemahan satu hari), persami (perkemahan sabtu minggu) dan perkemahan lebih dari 3 hari. "Dalam pelaksanaan perkemahan prosesnya diawali dengan persiapan, pelaksanaan, acara, penyelesaian, dan evaluasi" (Sukiyat, 2020:174). Kegiatan yang diakhiri dengan evaluasi bisa dilakukan dengan cara mencatat prestasi kegiatan peserta didik selama berkemah baik perorangan maupun beregu, mengajukan pertanyaan kepada peserta, perubahan sikap, melihat kesehatan peserta didik, kekurangan, kesalahan serta hambatan dicatat guna perbaikan, menyusun laporan hasil berkemah oleh pembina untuk dilaporkan kepada orang tua. Dalam perkemahan sangat mengajarkan banyak pelatihan hidup yang dituntut untuk memupuk kemandirian, tanggung jawab atas diri sendiri juga kelompok dan belajar menyesuaikan diri dengan lingkungan yang mungkin tidal sesuai dengan kebiasaan lingkungan rumah.

Pemahaman peneliti menjelaskan bahwa perkemahan adalah kegiatan ekstrakurikuler Pramuka yang berada di alam bebas guna 
untuk mengenal kekuasaan Tuhan YME, dan memupuk rasa kberanian, kamandirian, dan bertahan hidup dengan menggunakan bahan dan alat dari alam.

\section{(b) Api Unggun}

Api unggun dulunya digunakan untuk mencari kehangatan dan menjauhkan diri dari binatang buas sehingga pada saat ini digunakan untuk ajang menampilkan kreasi di medan terbuka, berupa lapangan yang cukup luas, permukaannya rata, suasana sekitar lapangan tenang dan tidak berangin. Kegiatan api unggun juga mempunyai tujuan "mendidik peserta didik untuk mempunyai keberanian, percaya pada diri sendiri melalui cara berpentas" (Sukiyat, 2020:175). Kegiatan api uggun mempunyai nilai pendidikan yang baik untuk membentuk karakter peserta didik yaitu "mempercepat persaudaraan, memupuk kerja sama, gotong royong, menambah rasa kebenarian, percaya diri, membuat suasana kegembiraan, suasana kebebasan dalam mengembangkat bakat" (Sukiyat, 2020:175). Dari pengertian di atas peneliti menyimpulkan bahwa kegiatan api unggun adalah kegiatan ekstrakurikuler Pramuka yang berada di lahan yang luas dengan menyalakan api unggun dan persembahan penampilan kreasi dari anggota pramuka guna untuk melatih keberanian.

\section{(c) Upacara}

Upacara adalah serangkaian perbuatan yang ditata dalam suatu ketentuan peraturan yang wajib dilaksanakan dengan khidmat dan tertib, sehingga merupakan kegiatan budi pekerti luhur yang bertujuan membentuk manusia patriot Indonesia yang berbudi pekerti luhur dan taqwa kepada Tuhan Yang Maha Esa dengan harapan peserta didik memiliki rasa cinta kepada tanah air, bangsa dan agama memiliki rasa tanggung jawab dan disiplin pribadi, memiliki jiwa gotong-royong dan percaya, selalu tertib dalam menjalani kehidupan sehari-hari, dapat

Implementasi Kegiatan Ekstrakurikuler dalam Membentuk Karakter Peserta Didik di Mts. 
memimpin dan dipimpin, dapat melaksanakan upacara dengan hidmat dan tertib.

Kegiatan upacara dalam Pramuka biasanya terdiri dari pengibaran dan penghormatan kepada Sang Saka Merah Putih, pembacaan Pancasila, pembacaan moral Pramuka, doa dan bentuk barisan sesuai dengan ketentuan yang berlaku. Jenisnya upacara dalam Pramuka tidak hanya satu, diantaranya:"upacara umum, upacara pembukaan dan penutupan latihan, upacara pelantikan, upacara kenaikan tingkat kecakapan, upacara pindah golongan, upacara meninggalkan ambalan atau racana" (Sukiyat, 2020:177). Sehingga peneliti dapat memahami kegiatan upacara wajib diadakan oleh Pembina Pramuka kepada anggota dengan membiasakan untuk baris rapi, patuh akan perintah komandan agar anggota dapat memiliki jiwa NasionalismePatriotisme.

\section{Karakter Peserta Didik}

Menurut kamus besar Bahasa Indonesia karakter adalah "watak atau tabi'at" yaitu sifat batin manusia yang mempengaruhi segenap pikiran dan tingkah laku yang membedakan seseorang dari yang lainnya. Secara etimologis karakter berasal dari kata charakter (Yunani) semula berarti alat untuk mengukir. Dalam perkembangan berikutnya diartikan sebagai sifat, ciri-ciri yang menandai kepribadian seseorang sekaligus membedakannya dari sifat orang lain. Sedangkan dalam the oxford English reference dictionary, kata character diartikan sebagai "kekuatan moral”. Hal ini selaras dengan Magawangi dalam Sukiyat (2020:69) mendefinisikan karakter (watak) adalah sitilah yang diambil dari bahasa Yunani juga yang berarti "to mark" (menandai), yaitu menandai tindakan atau tingkah laku seseorang sehingga seseorang bisa disebut "orang yang berkarakter" apabila tingkah lakunya sesuai dengan moral yang berlaku.

Implementasi Kegiatan Ekstrakurikuler dalam Membentuk Karakter Peserta Didik di Mts. 
Karakter peserta didik bisa dibentuk dengan cara memberikan contoh dan ajakan. Dalam pembelajaran di sekolah juga telah disepakati untuk mensintegrasikan sembilan nilai karakter untuk membentuk karakter peserta didik, sembilan karkater antara lain: "(1) Cinta Tuhan dan segenap ciptaan-Nya, (2) Kemandirian dan Tanggung Jawab, (3) Kejujuran/Amanah, Bijaksana, (4) Hormat dan Santun, (5) Dermawan, Suka Menolong dan Gotong Royong, (6) Percaya diri, Kreatif, dan Pekerja Keras, (7) Kepemimpinan dan Keadilan, (8) Baik dan Rendah Hati, (9) Toleransi, Kedamaian, dan Kesatuan” (Megawangi dalam Masganti, 2012:165). Hal ini sesuai dengan karakter perserta didik yang bersumber dari agama, Pancasila, budaya dan menjadi tujuan pendidikan nasional ada 18 nilai, yaitu: “1) Jujur, 2) Toleransi, 3) Disiplin, 4) Kerja Keras, 5) Kreatif, 6) Mandiri, 7) Demokratis, 8) Rasa Ingin Tahu, 9) Semangat Kebangsaan, 10) Cinta Tanah Air, 11) Menghargai Prestasi, 12) Bersahabat atau komunikatif, 13) Cinta Damai, 14) Gemar Membaca, 15) Peduli Lingkungan, 16) Peduli Sosial, 17) Tanggung Jawab, 18) Religius”. (Puskur dalam Sukiyat, 2020:85).

\section{Metode Penelitian}

1. Jenis deskripstif dengan pendekatan kualitatif.

2. Sumber Data Primer (Pembina Osis, Pembina Pramuka, dan 2 anggota pramuka) dan skunder (jadwal kegiatn ekstra, data siswa dan guru, pembina ekstra dan lain-lain).

3. Teknik pengumpulan data menggunakan observasi, wawancara dan dokumentasi.

4. Analisis data menggunakan teknik Miles dan Huberman yaitu data reduction, data display, dan conclusion (Sugiyono, 2016: 246). Analisis data terdiri dari reduksi data, penyajian data, dan kesimpulan.

5. Keabsahan data menggunakan triangulasi sumber dan triangulasi teknik.

\section{Pembahasan}

\section{Kegiatan Ekstrakurikuler di MTs. Al-Maarif Wuluhan Jember.}

Implementasi Kegiatan Ekstrakurikuler dalam Membentuk Karakter Peserta Didik di Mts. Al-Maarif Wuluhan Jember Amirotun Nahdliyah, Arina Faiqotul Himmah 
a. Kegiatan ekstrakurikuler di MTs. Al-Maarif Wuluhan Jember terdapat 8 jenis Ekstrakurikuler.

Kegiatan ekstrakurikuler ada 2 yaitu ekstrakurikuler yang bersifat sesaat dan berkelanjutan (Prihatin, 2014:160-161). Sesaat artinya kegiatan dilakukan di waktu tertentu seperti baksos dan PMR, sedangkan berkelanjutan maksudnya kegiatan dilakukan secara berkala sampai selesai satu semester atau periode. Dengan begitu kegiatan ekstrakurikuler yang telah dikembangkan di MTs. Al-Maarif Wuluhan Jember sejak 3 tahun lalu ada 8 jenis yaitu Sanggar Olimpiade, Pramuka Tsalma Scout, Pagar Nusa, Volly Ball, Tsalma Futsal Club, Bulu tangkis, Majlis Sholawat, dan Tahfidzul Quran juga termasuk dalam kegiatan ekstrakurikuler yang bersifat berkelanjutan karena dilaksanakan secara terus-menerus dilakukan setiap hari Sabtu mengikuti program sekolah PHS (Program Hari Sabtu). Untuk kegiatan ekstrakurikuler yang bersifat sesaat belum ada.

\section{b. Pendaftaran kegiatan ekstrakurikuler}

Untuk mengikuti kegiatan ekstrakurikuler di MTs. Al-Maarif Wuluhan Jember harus mengikuti prosesdur pendaftaran terlebih dahulu agar namanya tercantum dalam bidang ekstra yang dipilih. Adapun pendaftarannya terdapat 2 perincian yaitu:

1) Pendaftaran kegiatan ekstrakurikuler bagi peserta didik baru dilakukan saat mengisi formulir pendaftaran sekolah pada kolom ekstrakurikuler yang ditandatangani langsung oleh orang tua.

2) Pendaftaran kegiatan ekstrakurikuler bagi peserta didik naik tingkatan dilakukan di awal semester atau ajaran baru melalui angket pemilihan kegiatan ekstrakruikuler.

\section{c. Tentatif kegiatan ekstrakurikuler}

Urutan kegiatan ekstrakurikuler khusus hari Sabtu diawali dengan pembacaan asmaul husna dan yasin pada pukul 07.00-07.15 WIB yang 
dipimpin oleh pak guru dari kantor, pada pukul 07.15-08.00 WIB sholat dluha yang dipimpin oleh imam yang telah dijadwal oleh pengurus kelas yang bertempat di kelas masing-masing. Kemudian pukul 08.00-10.30 WIB kegiatan ekstrakurikuler. Pukul 10.30-11.00 WIB evaluasi kegiatan, berdoa dan peserta didik dipersilahkan untuk menuju rumah masingmasing.

Sedangkan pada jumat sore dimulai pukul 13.30-14.00 WIB upacara pembukaan, berdoa, PBB. Pukul 14.00-15.30 WIB latihan materi pramuka sesuai pilihan anggota sendiri. Kemudian kegiatan ditutup dengan apel pentutupan, PBB, dan yel-yel sampai pukul 16.00 WIB tepat. Peserta didik dipersilahkan menuju rumah masing-masing.

\section{d. Penilaian kegiatan ekstrakurikuler}

Penilaian kegiatan ekstrakurikuler dilihat dari segi kemampuan, kehadiran dan kektifan peserta didik. Kategori penilaian meliputi:

1) Nilai A kategori untuk peserta didik yang aktif, kemampuannya memenuhi kriteria yang ditentukan.

2) Nilai B untuk kategori peserta didik yang memiliki kemampuan sesuai kriteria yang ditentukan namun kehadiran kurang aktif.

3) Nilai $\mathrm{C}$ kategori untuk peserta didik yang memiliki kamampuan kurang memenuhi kriteria yang ditentukan, kehadiran pun kurang aktif.

4) Sedangkan nilai $\mathrm{D}$ kategori untuk peserta didik kurang sekali memperhatikan keaktifan kehadiran dalam mengikuti kegiatan ekstra sehingga kemampuanpun sangat tidak sesuai kiteria/KKM.

\section{Implementasi Kegiatan Ekstrakurikuler dalam Membentuk Karakter Peserta Didik di MTs. Al-Maarif Wuluhan Jember.}

\section{a. Kegiatan Pramuka umum}

Implementasi Kegiatan Ekstrakurikuler dalam Membentuk Karakter Peserta Didik di Mts. Al-Maarif Wuluhan Jember 
1) Pembelajaran tentang pramuka dasar berupa pengenalan lambang pramuka, pancasila, dasa dharma, tri satya dan lain-lain dapat membentuk karakter nilai rasa ingin tahu, semangat kebangsaan, cinta tanah air, menghargai prestasi para pahlawan,

2) PBB (Peraturan Baris-Berbaris) dapat membentuk karakter peserta didik berupa disiplin, petuh terhadap perintah dan berjiwa patriotisme.

3) Kegiatan pembiasaan seperti masuk kelas tepat waktu, mengerjakan tugas, merawat alat kelas, membuang sampah pada tempatnya, berjabat tangan dengan guru akan membentuk karakter disiplin, bertanggung jawab, jujur, cinta damai, peduli lingkungan, peduli sosial, mandiri, toleransi, sopan, beriman dan bertaqwa kepada Tuhan YME.

\section{b. Kegiatan Pramuka Khusus}

\section{1) Perkemahan}

Banyaknya kegiatan dalam perkemahan yang sangat menguras tenaga fikiran dan fisik karena melibatkan banyak orang dapat membentuk karakter peserta didik dengan cepat. Pembentukan karakter itu didapat melalui beberapa kegiatan dalam perkemahan, yaitu:

\section{a) Mendirikan tenda}

Kegiatan ini dapat membentuk karakter peserta didik berupa mandiri, toleransi antar anggota, kerja keras, peduli sosial dalam membangun kekompakan dan saling membantu sesama, tanggung jawab.

\section{b) Penjelajahan}

Masih banyak lagi macam kegiatan di dalam penjelajahan yang masih dalam lingkungan perkemahan yaitu peta pita, menaksir (tinggi tiang, arus sungai, dan lain-lain, panorama sket, SMS (sandi, semaphore, morse), P3K, PPGD, permainan uji nyali, KIM (Ketajaman Indra Manusia) seperti mencium, meraba, menebak 
gambar, ketangkasan dapat membentuk peserta didik berkarakter toleransi, kreatif, rasa ingin tahu, menghargai prestasi, cinta damai, tanggung jawab, keberanian, cermat dan terampil.

\section{c) Yel-yel}

Yel-yel merupakan kegiatan hiburan yang juga dapat membantu pembentukan karakter peserta didik berupa kreatif, bersahabat atau komunikatif, demokratis dan mandiri.

\section{d) Pioneering}

Melihat dari kegiatan pioneering di pramuka, peserta didik secara tidak disengaja dengan sendirinya akan mempunyai karakter kreatif, kerja keras, rasa ingin tahu, peduli sosial, disiplin dan tanggung jawab.

\section{e) Ujian SKU dan SKK}

Jika peserta didik menguasai dan lulus ujian SKU dan SKK, karakter yang terbentuk pada peserta didik di kegiatan ini ialah 1) keimanan kepada Tuhan YME, 2) Ketakwaan kepada Tuhan YME, 3) kecintaan pada alam, 4) kecintaan kepada sesama manusia, 5) kecintaan kepada tanah air Indonesia, 6) kecintaan kepada bangsa Indonesia, 7) kedisiplinan, 8) keberanian, 9) kesetiaan, 10) tolongmenolong, 11) bertanggung jawab, 12) jernih dalam berfikir, 13) jernih dalam berkata. 14) jernih dalam berbuat, 15) hemat, 16) cernat, 17) bersahaja, 18) rajin, dan 19) terampil.

\section{2) Api Unggun}

Meskipun kegiatan api unggun terlihat santai ternyata kegiatan ini mengandung pembentukan karakter peserta didik kerja sama, keberanian, percaya diri, dan kreatif.

\section{3) Upacara}

Karakter yang terbentuk saat kegiatan upacara yaitu cinta tanah air, disiplin, tanggung jawab, percaya diri, tertib, membentuk diri yang

Implementasi Kegiatan Ekstrakurikuler dalam Membentuk Karakter Peserta Didik di Mts. 
bisa memimpin dan dipimpin, dapat merasakan khidmat upacara, cinta bangsa dan meningkatkan ketaqwaan kepada Tuhan Yang Maha Esa.

Tidak hanya itu, dalam kegiatan upacara masih ada kegiatan yang dapat membentuk karakter seperti PBB dan P3K atau PPGD.

Dari beberapa paparan kegiatan di atas sudah menunjukkan bahwa harapan yang ingin dicapai pendidikan Nasional dan gerakan pramuka yaitu peserta didik mempunyai karakter jujur, toleransi, disiplin, kerja keras, kreatif, mandiri, demokratis, rasa ingin tahu, semangat kebangsaan, cinta tanah air, menghargai prestasi, bersahabat atau berkomunikatif, cinta damai, gemar membaca, peduli lingkungan, peduli sosial, tanggung jawab, religious, keimanan kepada Tuhan YME, ketakwaan kepada Tuhan YME, kecintaan pada alam, kecintaan pada sesama manusia, kecintaan kepada tanah air Indonesia, kedisiplinan, keberanian, kesetiaan, tolong-menolong, bertanggung jawab, jernih dalam berfikir, jernih dalam berkata, jernih dalam berbuat, hemat, cermat, bersahaja, rajin dan terampil telah terbentuk melalui kegiatan ekstrkurikuler pramuka yang diselenggarakan oleh MTs. Al-Maarif Wuluhan Jember meliputi perkemahan, api unggun dan upacara.

\section{Faktor Pendukung dan Penghambat Proses Kegiatan ekstrakurikuler di} MTs. Al-Maarif Wuluhan Jember.

\section{a. Faktor pendukung}

1) Adanya ajang perlombaan yang bisa menambah semangat peserta didik untuk menekuni ekstrakurikuler yang diikuti.

2) Hadirnya anggota pramuka senior yeng membantu membina untuk melatih anggota pramuka.

3)Pada era pendidikan yang sifatnya desentralisasi yaitu otonomi sekolah sepenuhnya dikembalikan kepada sekolah dengan syarat tidak keluar dari aturan pemerintah

Implementasi Kegiatan Ekstrakurikuler dalam Membentuk Karakter Peserta Didik di Mts. 
4)Pentingnya jati diri seseorang untuk menemukan karakter dan bakat sesuai dengan Skill masing-masing.

5) Aktifnya pembina untuk hadir mendampingi kegiatan ekstrakurikuler.

6) Kordinasi yang baik antar pembina dengan pembina yang lain.

7) Adanya dukungan dari orang tua, guru dan pembina.

8) Adanya waktu tambahan latihan pramuka pada hari Jumat sore.

\section{b. Faktor Penghambat}

1) Kurangnya komitmen peserta didik dengan apa yang mereka pilih.

2) Kualitas minat yang berbeda-beda

3) Tidak adanya silabus kegiatan secara pasti, semua mengandalkan kreatifitas pembina.

4) Kurangnya lengkapnya fasilitas seperti tongkat, tali air dan peluit.

5) Kurangnya tenaga pendidik atau pembina.

6) Kurangnya motivasi dan contoh dari alumni.

7)Dana.

\section{E. Kesimpulan}

1. Kegiatan ekstrakurikuler di MTs. Al-Maarif Wuluhan Jember dilakukan hanya pada hari Sabtu sebanyak 8 jenis kestrakurikuler yang bersifat berkelanjutan yaitu Sanggar Olimpiade, Pramuka Tsalma Scout, Pagar Nusa, Volly Ball, Tsalma Futsal Club, Bulu tangkis, Majlis Sholawat, dan Tahfidzul Quran melalui pendaftaran yang mana penilaian kegiatan dilihat dari segi keaktifan dalam mengikuti tentatif kegiatan secara tertib mulai pukul 07.00 WIB sampai 11.00 WIB.

2. Implementasi kegiatan ekstrakurikuler dalam membentuk karakter peserta didik terdapat dalam kegiatan ekstrakueikuler pramuka yaitu perkemahan, api unggun dan upacara. Karakter peserta didik yang terbentuk dalam kegiatan itu adalah karakter jujur, toleransi, disiplin, kerja keras, kreatif, mandiri, demokratis, rasa ingin tahu, semangat kebangsaan, cinta tanah air, 
menghargai prestasi, bersahabat atau berkomunikatif, cinta damai, gemar membaca, peduli lingkungan, peduli sosial, tanggung jawab, religious, keimanan kepada Tuhan YME, ketakwaan kepada Tuhan YME, kecintaan pada alam, kecintaan pada sesama manusia, kecintaan kepada tanah air Indonesia, kedisiplinan, keberanian, kesetiaan, tolong-menolong, bertanggung jawab, jernih dalam berfikir, jernih dalam berkata, jernih dalam berbuat, hemat, cermat, bersahaja, rajin dan terampil.

3. Faktor pendukung proses kegiatan ekstrakurikuler di MTs. Al-Maarif Wuluhan Jember meliputi adanya ajang perlombaan, hadirnya anggota pramuka senior, aktifnya kehadiran dan kordinasi antar pembina, adanya dukungan orang tua dan waktu tambahan pada Jumat sore. Sedangkan faktor penghambatnya ialah kurangnya komiten peserta didik, tidak ada silabus yang pasti, kurangnya sarana dan prasarana, kurangnya tenaga pendidik di bidang pramuka khususnya dan dana.

\section{F. Saran}

1. Untuk lembaga yang diteliti

Terus kembangkan dan lestarikan program serta kegiatan ektrakurikuler yang ada. Lebih baik ditambah lagi cabang ektrakurikulernya dan lebih kreatif lagi dalam mencari inovasi kegiatan agar lebih banyak menampung pengembangan bakat dan membentuk karakter peserta didik.

2. Untuk peneliti selanjutnya

Diharapkan dapat menemukan hal-hal baru yang lebih lagi dari proses penelitian yang dilakukan terutama tentang manajemen kesiswaan bagian kegiatan ekstrakurikuler.

Implementasi Kegiatan Ekstrakurikuler dalam Membentuk Karakter Peserta Didik di Mts. Al-Maarif Wuluhan Jember 


\section{G. Daftar Rujukan}

Al Qur'an Kudus. Al Kudus Al Qur'an dan terjemahnya. Kudus: PT. Buya Barokah.

Billah, Muhammad Al Mutawaqil. 2017. Nilai-nilai pendidikan karakter dalam kumpulan puisi Playon karya F. Aziz Manna. Skripsi. Malang: Fakultas Pendidikan Ilmu Sosial dan Humaniora IKIP BUDI UTOMO MALANG.

Halim, Fanny. Tanpa tahun. Salinan lampiran peratran mentri pendidikan dan kebudayaan Republik Indonesia. (ONLINE), (https://adoc.tips/pedomankegiatan-ekstrakurikuler.html.Pdf, diunduh pada 29 April 2020).

Hermino, Agustinus. 2016. Manajemen Kemarahan Siswa. Yogyakarta: Pustaka Belajar

Hidayat, Rahmat dan Candra Wijaya. 2017. Ayat-ayat Al-Quran Tentang Manajemen Pendidikan Islam. Medan: LPPPI.

Ibeng, Parta. 2020. Pengertian Implementasi. (ONLINE), (https://pendidikan.co.id/implementasi-adalah/ diakses pada 26 April 2020).

Johan, Adi. Tanpa tahun. Pengelolaan Kegiatan Ekstrakurikuler. (ONLINE), (https://adoc.tips/pengelolaan-kegiatan-ekstrakurikuler. Html.Pdf. diunduh pada 29 April 2020).

Karwati dan Donni. 2015. Manajemen kelas (classroom management) guru profesional yang inspiratif, kreatif, menyenangkan, dan berprestasi. Bandung: Alfabeta.

Mahargiyanti, Meilia Ajeng Hening. 2017. Pengembangan Bakat dan minat melalui kegiatan ekstrakurikuler pramuka pada siswa MTs Muhammadiyah 07 Purbalingga di Kejobong. Skripsi. Purwokerto: Fakultas Dakwah IAIN PURWOKERTO.

Mardalis. 2014. Metode Penelitian Suatu Pendekatan Proposal. Jakarta: Bumi Aksara.

Masganti. 2012. Perkembangan Peserta Didik. Medan: Perdana Publishing.

Maunah, Binti. 2009. Landasan pendidikan. Yogyakarta: Teras.

Nata, Abuddin. 2016. Pendidikan dalam Prespektif al Quran. Jakarta Prenadamedia Group.

Implementasi Kegiatan Ekstrakurikuler dalam Membentuk Karakter Peserta Didik di Mts. 
Nata, Abuddin. 2018. Manajemen Pendidikan Mengatasi Kelemahan Pendidikan Islam di Indonesia. Jakarta: Prenadamedia Group.

Pribadi, Kelik Gunawan. 2015.Manajemen Ekstrakurikuler. Tesis yang diajukan oleh mahasiswa Studi Pasca Sarjana Jurusan Manajemen Pendidikan Islam IAIN Surakarta.

Prihatin. 2014. Manajemen peserta didik. Bandung: Alfabeta.

Ratna, Nyoman Kutha. 2014. Peranan Karya Sastra, Seni dan Budaya dalam Pendidikan Karakter. Yogyakarta: Pustaka Pelajar.

Saefulloh. 2012. Manajemen Pendidikan Islam. Bandung: CV. Pustaka Setia.

Salinan Lampiran Peraturan Menteri Pendidikan Dan Kebudayaan Republik Indonesia Nomor 62 Tahun 2014 tentang Kegiatan Ekstrakurikuler Pada Pendidikan Dasar dan Pendidikan Menengah. (ONLINE), (https://www.slideshare.net/gilangasridevianty/lampiran-permen-nomor-62th-2014).

Sugiyono, 2016. Metode penelitian kuantitatif, kualitatif dan R\&D. Bandung: Alfabeta.

Sukardi. 2008. Evaluasi Pendidikan Prisnsip dan Operasionalnya. Jakarta: Bumi Aksara.

Sukiyat, 2020. Pendidikan Kepramukaan Berbasis Pendidikan Karakter. Surabaya: CV. Jakad Media Publishing.

Suryabrata, Sumadi. 2010. Metode Penelitian. Jakarta: PT. Raja Grafindo Persada.

TIM DOSEN Administrasi Pendidikan Universitas Pendidikan Indonesia. 2009. Manajemen Pendidikan. Bandung: Alfabeta.

Ubaidah, Siti. 2014. Manajemen Ekstrakurikuler dalam Meningkatkan Mutu Sekolah. Jurnal kependidikan islam IAIN SULTHAN THAHA FAIFUDDIN. 